\title{
Public Management Failure in Africa: The Case of Nigeria
}

\author{
Felix F. Barikor, Ph.D* \\ Assistant Professor, Affiliate of Rivers State University, Port Harcourt, Nigeria
}

\section{*Corresponding Author}

Felix F. Barikor

\author{
Article History \\ Received: 10.11 .2020 \\ Accepted: 22.11.2020 \\ Published: 30.11 .2020
}

\begin{abstract}
This paper studies some factors responsible for Nigeria's Poor Management Leadership Quality Generally and the Poor Leadership in the Management of the ECOMOG Peace Support Operations in Liberia 1990-1999. The paper is a result of a combined research efforts conducted on some factors responsible for Nigeria's poor management leadership quality and the analysis of External and Internal Factors that Impacted the Effectiveness of Nigerian Political Leaders in ECOMOG Peace Support Operation in Liberia from 1990 to 1999 and a detailed review of late Professor Claude Ake's thoughts on African leadership and its Political Economy. The thoughts of O.J. Dada on Nigeria on these issues are also reviewed in some details and a few examples of poor management or outright mismanagement are equally analyzed at the end of the paper. A brief review of factors impacting the effectiveness of Nigerian political leaders management skills in domestic and international affairs indicate that the key factors are external influence of the OECD countries who fund the Bretton Woods institutions responsible for providing the African post-independent development agenda, the internal political conditions which are heavily impacted by the colonial legacy which emphasizes power retention to the detriment of development programs [1] and brought about poor leadership management skills which finally resulted into the tendency to be corrupt [2]. Most of the scholars and other political commentators on African political economy agree that external factors affect the economic development of the continent just like internal factors. The internal factors are concerned mostly with the qualities of the political leadership which is negatively impacted by incompetence, mismanagement and outright corruption [2]. Research conducted for this paper revealed that the ECOWAS desk officer in Nigerian Ministry of Foreign Affairs complained about some dishonest military officers who absconded with millions of dollars meant for the peacekeepers in the Nigerian ECOMOG contingents in Liberia from 1990 to 1999 [3].
\end{abstract}

Keywords: Poor Leadership, ECOMOG, Public Management Failure.

\section{INTRODUCTION}

The modern paradigm of public management analysis is based on the analysis of the effectiveness or competence of the political leadership of the country in good governance and the ability of that leadership to improve or raise the standard of living of the people in the country concerned using the Human Development Index-HDI. The higher a country's Human Development Index is, the more developed it is classified to be. On the reverse side, the poorer a country is, the more incompetent its leaders are said to be and most African countries fall into this category including Nigeria [2].

This section analyzes the external and internal factors impacting the effectiveness of African leaders in public management and international affairs and goes on to provide ample evidence of mismanagement of available resources and corruption which have nothing to do with external factors. The key fact here is that the Western world deliberately denied African countries the resources, material (investments) and human (i.e. technical) which they need to develop (Ake and Dada agreed on this) but what are African leadership doing with their available meager resources?

During the Nigerian led ECOMOG intervention in Liberia for instance, despite the fact that the military leadership was doing all it could to proof its superiority in the sub-region, some basic problems like the provision of

Copyright (C) 2020 The Author(s): This is an open-access article distributed under the terms of the Creative Commons Attribution 4.0 International License (CC BY-NC 4.0) which permits unrestricted use, distribution, and reproduction in any medium for noncommercial use provided the original author and source are credited. 
sufficient vessels for the Nigerian naval contingent was all too common. ECOMOG forces that needed sealift had to wait for a considerable length of time for the navy to do their jobs due to insufficient number of vessels according to Navy Captain A.L. Akintola [4].

Again, what is the key Evidence of the Lack of Effectiveness of Nigerian political leaders in International Affairs? The study analyzes published materials on evidence of the Lack of Effectiveness of Nigerian political leaders in International Affairs as the main source of the data. This section was originally intended to analyze the leadership role of the specialized non-military personnel but unfortunately all available evidence both from military, former and nonmilitary scholars confirmed that no non-military personnel from Nigeria was involved in the Nigerian contingent to ECOMOG peace support operation in Liberia except the United Nations which had Special Representative for Liberia and some humanitarian agencies.

\section{PUBLIC MANAGEMENT FAILURE IN NIGERIA}

Again, talking about the lack of effectiveness of the Nigerian leadership, let us take the shortage of vessels mentioned above for example again. Not only are the vessels insufficient in number, even those that had been provided lack adequate maintenance according to Akintola:

The ships available for sealift operation sailed in poor state of readiness. The logistic support problems were compounded because of distance from base and inadequate repair facilities. The ships lacked adequate storage facilities, which limited their endurance at sea. There were also inadequate onboard spare parts holding and limited Petroleum Oil and Lubricant (POL) supply [4].

One of the greatest challenges facing the Nigerian nation in it development process is the apparent failure of the political leadership due to their inability to respond adequately to the factors that impede development and without development, how can Nigeria enhance internal security? Restoring peace in Liberia cannot enhance internal security in Nigeria as long as certain factor continue to impede development. The factors impeding development are many and vary according to studies by eminent African scholars such as Claude Ake and O.J. Dada beside many others. These factors may include internal and external environmental factors such as, colonial legacy, social pluralism and its centrifugal tendencies, corruption of leaders, poor labor discipline, the lack of entrepreneurial skills, poor planning and incompetent management (lack of effective basic public management), inappropriate policies, the stifling of market mechanisms, low levels of technical assistance, the limited inflow of foreign capital, falling commodity prices and unfavorable terms of trade, and low level of saving and investment [1].

Some of their failings are incompetence and outright corruption. Otherwise, how could a leader procuring naval vessels for multipurpose sealift operations procure vessels that could not beach an army tank except on prepared beachheads? A battleship? This is incredible but it was the case according to Captain Akintola:

NNS AMBE could not beach Army Tanks at Freetown. An attempt to replenish NNS AMBE and NNS EKUN at sea by MV VICTORY REEFER almost ended in a disaster because the ship was ill-equipped for replenishment at sea. That is, the Nigerian Navy lacked underway replenishment capability, which ought to have formed part of the Nigerian Navy Fleet Auxiliary exercising at all times with the ships [4].

Most of these factors rest squarely on the shoulders of the leader and leaders with a combination of the right qualities including the right skills are what Africa needs to move forward in its quest for development and without development internal security of Nigeria will remain elusive [2].

Ake further argues that development was not even on the agenda in the first place and that although all of the factors above may impede development, the greatest impediments to development are the political conditions in Africa which revolve around the political leadership. The political leadership of Nigeria at that time as earlier mentioned was completely in the hands of the military. Let us not also forget that the military president then, General Ibrahim Babangida had been variously accused by both Nigerians and foreigners that he had a personal hidden agenda that motivated his action in Liberia [5].

He goes on to "explain how African politics has been constituted to prevent the pursuit of development and the emergence of relevant and effective development paradigms and programs" [1].

The problem of poor leadership had been identified as one the greatest challenges that the Nigerian contingent to ECOMOG peace support operations in Liberia faced by no other than a veteran of the ECOMOG peace support operations in Liberia, Lieutenant-Colonel Festus B. Aboagye, according to Osita Nweke: 
It should be noted that Aboagye's assertion that 'Just as disparities in equipment and levels of training impact on force effectiveness and morale, so do poor administration and logistics adversely affect the morale and operations of troops', was apt [6].

In a paper presented by O. J. Dada [2] entitled "Strengthening the African Political Leadership Capacity for Development: Key Challenges", he observes that the "Sub-Saharan Africa (SSA) is plagued with three diseases: Poor Leadership; Poor Leadership and Poor Leadership". He goes on to explain that no matter the other underlying factors that cause the slow development on the continent, poor leadership has been singled out as the most important factor affecting development on the continent.

A cursory review of the link between crime and poverty indicates that hundreds of publications link crime and insecurity to poverty (unemployment) and under-development which goes to confirm that restoring peace and stability in the sub-region and Nigeria can only be possible if the leadership tackles development issues head-on to reduce poverty (Ward, October 12, 2013) (www.nationaldialoguenetwork.org/povertyandcrime).

To buttress his argument, Dada cites Adei [7] as positing that "Leadership is cause, everything else is effect", adding that there is the need for the sub-region to evolve a leadership system that will be globally focused while maintaining internal cohesion. In his effort to vehemently stress the importance of the role the leadership of the region has to play for its development, he quotes Nelson Mandela as saying that "Africa is beyond bemoaning the past for its problems. The task of undoing the past is on the shoulders of African leaders themselves, with support of those willing to join in the continental renewal" [2].

So far, it is very clear that Nigerian armed forces mediocre performance in ECOMOG peace support operation in Liberia revolves around the quality of leadership of the country and when it comes to the question of good performance in any endeavor or economic development the quality of the leadership cannot be ruled out as well. On October $1^{\text {st }} 2020$, Nigeria was sixty years old as an independent nation and yet, there is very little to show in terms of physical development of the nation and the uplifting of the wellbeing of the people-No regular power supply, broken educational system, broken down road networks, no public and property safety etc. With the abundant material and human resources available to the country at independence, no one would have imagined that Nigeria and other subSaharan countries would be in this position six decades after independence according to Dada [2, 8].

When Claude Ake emphasizes that of all the problems impeding development in Africa, political conditions are the greatest culprits, it is also referring to the political leadership that is unable or incompetent to lead the continent in the right direction despites all the other challenges. He argues that the colonial legacies which includes the imposition of agriculture as the mainstay of the economy impeded development but it was the leadership aspect of the colonial legacies which include absolutism and arbitrariness as the major features of state power which African leaders inherited that is responsible for the backwardness in the post-colonial situation.

This assertion is one key problem of Nigeria at that time because the country was under an absolute military dictatorship and so it would have been a miracle if the leadership had done more than it did. Everybody agreed that ECOMOG peace support operation in Liberia had a relative success but at what price? Most of the casualties recorded were attributed to equipment failures or inadequate equipment. Besides, excessive financial resources were expended to achieve that relative success for instance, when an officer absconded with the funds meant for the operation to continue, another fund was provided [3]. That is to say that had there not been more than sufficient financial resources at the disposal of the military political leadership nothing would have been achieved in real sense.

The political leadership according to Ake gradually alienated their followership and then they turned around to use coercion to contain political dissent and that violence eventually attracted the military who are themselves specialists in violence to the political scene through military coups. The inherited emphasis on state power ended up making power to be everything to the political leadership and so they will stop at nothing to acquire and maintain power making development to take the back seat after replacing the nationalist ideology of self-government with the ideology of development. The current military crackdown on peaceful protesters in Nigeria going on this year 2020 is clear example of poor leadership trying to hold-on to power at all cost (ChannelsTV. Nigeria, Monitored from Washington DC on 1021-2020)

Most of this discourse assumed that the government in place was a democratically elected one but unfortunately, in Nigeria's case at that time it was a military dictatorship that was in charge of political leadership which means that the political nightmare situations being discussed here were the political realities in Nigeria at that time and unfortunately, up to this time in 2020 . 
Ake adds that knowing that abandoning development will cost them their support, they now pass on the responsibility of development to their foreign patrons and thereby willingly accepting economic dependency while talking of self-reliance at the same time, he maintains. This according to Ake was how the development paradigm fell back to the West but not for too long as they soon learned that their external development agents' interests were in conflict with their own development agenda and this scenario eventually led to a conflicting agenda [1].

Now it is fashionable to blame the international development agencies like the International Monetary Fund (IMF) and the World Bank for Africa's and in this case, Nigeria's development failures but the above analysis by Claude Ake and Dada clearly put the blame on the African and ultimately, the Nigerian leadership.

Again using the ECOMOG peace support operation in Liberia as a case in point, some may wonder whether the political or the military leadership was to be blamed for the inadequacies that the Nigerian contingent to ECOMOG peace support operation in Liberia faced during its deployment but there is no doubt that they both share the blame since the military were also in charge of the political leadership in Nigeria during the period 1990 to 1999. Besides, like the ECOWAS desk officer of the ministry of foreign Affairs said, some military officers also misappropriated the funds that were appropriated for the running of the ECOMOG peace support operation in Liberia resulting in serious inadequacies reported by some veterans of the military like Group Captain A.R. Okanlawon:

For the decade long air support, the pilot to aircraft ratio average 1.5:1, a far cry from the world's average 3:1. In other words, the aircraft holding, as well as pilots to man them were inadequate for the task assigned. Offensive air supports in ECOMOG were adjudged successful, but the success was achieved at great cost and risk to the pilots, many of whom exhibited combat fatigue. It was just raw courage [9].

A good leader will provide all that the military needed for such an important undertaken like the ECOMOG peace support operation and it does not matter whether it was an economic development program or equipping a military force for a mission.

As noted earlier according to Claude Ake, the overwhelming emphasis on political survival completely marginalized any thought of pursuing the development of the newly independent nations including Nigeria and knowing that without putting the development ideology on their agenda they will be irrelevant, the agenda was passed on to the west who then designed the African development agenda.

Again, talking of too much emphasis on political survival, Abiodun Alao [5] argues that some of General Babangida's actions may have been motivated by political survival:

The main argument advanced in the chapter is that there was a blurred distinction between "personal" and "national" interests in Nigeria's foreign and domestic policies during the last decade of the twentieth century. The chapter also argues the desire of the Nigerian military to remain in control of domestic politics was a factor that influenced, at least in part, some of Nigeria's sub-regional policies [5].

Claude Ake continues by explaining that the complacency that African leaders derived from this arrangement did not last long and sooner than later they realized that they have left the major aspect of the policy management tasks to others whose interests were different from their own and then decided to design their own development agenda. He notes that before the general realization on the part of African leadership that they might be disappointed, only Zambia and Tanzania had attempted to take control of their own development agenda. Their development blueprints were contained in Tanzania's Arusha Declaration in 1967 and the Zambia's Mulungushi Declaration of 1968.

Analyzing what he considers to be competing agendas, Ake lists all the efforts aimed at promoting African development agenda under the auspices of the Organization of African Unity (OAU) now known as African Union (AU). The OAU efforts culminated into the 1980 Lagos Plan of Action which according to him is the classic work on African development strategy.

He also notes that the clash between this African development initiative and that of the Bretton Woods institutions on African development entitled Accelerated Development in Sub-Saharan Africa: An Agenda for Action 1981, was very significant. He explains that the Bretton Woods institutions document also known as the World Bank Report since it was written by World Bank, emphasized the very issue opposed to by African leaders, namely, the idea that Africa should concentrate on the production of primary raw materials for export which they believe was the main reason why they are underdeveloped in the first place.

Considering the issue being discussed, if the OECD countries manipulated the Bretton Woods institutions to impose an unfavorable or unworkable development agenda on the African leadership including Nigeria in a situation they 
could not help themselves because of lack of funding and enabling technology, what excuses do the leaders have for the peacekeeping efforts that the Nigerian leadership initiated and led the implementation for all the challenges the Nigerian contingent encountered on daily basis throughout the deployment?

Continuing on his analysis, Ake adds that the clash between the African development agenda and that of the Bretton Woods institutions lasted till 1986 when the OAU Council of Ministers met in Addis Ababa at its $15^{\text {th }}$ Extraordinary Session and approved a program of action which effectively meant a submission to the demands of the World Bank Reports on African development.

He notes that the OAU Assembly of Heads of States and Government had earlier approved the capitulation program called Africa's Priority Program for Economic Recovery, 1986-1990 (APPER) in Addis Ababa in August 1985 at its $21^{\text {st }}$ Ordinary Session. He further explains that despites the claim by African leaders that the new program was based on the Lagos Plan of Action, that its content was just based on the World Bank Reports adding that the United Nations also prepared its own African recovery plan known as the United Nations Program of Action for African Economic Recovery and Development, 1986-90 (UNPAAERD) to be implemented together. Yet, African leaders did their best in trying to implement the programs but the financial supports pledged by Western world did not materialize and instead the level of funding actually declined [1].

Once again, in trying to make a sense out of why African and Nigerian leaders failed in Liberia which is based on the preponderance of evidence of challenges faced by the Nigerian contingent to ECOMOG, a key issue of funding was raised in development and as Ake notes above, lack of funding could be blamed at the time they woke up and tried to implement development programs but that cannot be said of the failure of Nigerian leadership to perform better than they did given the enormous financial resources expended and the end result in Liberia. Despite the fact that they are credited with ending the crisis, far less amount of money could have achieved that modest success too.

Even the IMF structural adjustment programs which were widely opposed by African government continued to spread as an alternative approach to African development since no funding was supporting the UNPAAERD and APPER from their creator, Ake explains. He then concludes that African development cannot start in full swing until the conflicting development agenda issues are settled for good [1].

Prominent political economists like the late Professor Claude Ake agrees that failed or poor leadership was to blame for the dismal performance of the continent on development issues and by implication Nigeria but there appeared to be that very little is being done to turn the situation around especially in Nigeria. If there is any area of modern human civilization where the superiority of the nation's advanced development can be displayed it is in military operations just as the United States displayed in Operation Desert Storm or the First Gulf War-A war that many believed that America initiated and led the operation just like the ECOMOG peace support operation in Liberia by Nigeria.

What this means is that, Nigerian leaders who initiated this operation supposed to show-case how far Nigeria had gone even if it was all borrowed technology, the ability of the leadership to use the resources to provide the best for the Nigerian contingent would have demonstrated that there was a good and purposeful leadership Nigeria, yet billions of US dollars were expended with no clear record kept and the officers and men who served were owed their entitlement and even jailed in Nigeria for asking for their entitlements! (Nigerian Info FM, monitored in Port Harcourt, December 31, 2016).

This is beside the day to day struggles with challenges of inadequate supplies of almost everything needed to run the operations smoothly as Osita Nweke explains:

ECOMOG lacked adequate operational tools, to effectively engage in the peace enforcement. Lieutenant-Colonel Festus B. Aboagye in his book, ECOMOG: A Sub-Regional Experience in Conflict Resolution Management and Peacekeeping in Liberia", noted the ineffectiveness of the troops deployed in the peacekeeping operations" without support weapons, defense stores, communication or even transport". Liberia, he said, exposed the inadequacies of basic battle-craft expedients like maps, intelligence and communication equipment. Under the conditions of the modern battlefield, the ECOMOG veteran maintained that it is difficult to carry out successful operations without good maps and timely and accurate intelligence for the formulation of plans, which must then be quickly passed along secured communication lines for the conduct of successful operations [6].

Dada blames African development crisis on leadership crisis noting that “...leadership more than any other factor explains the relative progress or decline of nations, therefore, from the gory scenario painted above, it becomes imperative that Africa is faced with grave leadership governance challenges. This therefore underscores the importance 
of being given to the issue of leadership in development discourse with respect to Africa [2]. He goes on to cite Adei [7] to support his argument:

Why did most of those leaders, who were so successful as political liberators perform so dismally at delivering development? Why did they get to power through the ballot box and padlock it thereafter ...almost all the countries which attained independence in the 1950s and 1960s saw their liberators and their immediate successors become very bad nation builders who failed as development leaders? [2].

He also cites the former secretary-general of the OAU, Salem Ahmed Salem [10] as saying:

...Admittedly, the continent (SSA) is littered with failed institutions, mostly due to bad leadership. Devastating conflicts have been provoked and sustained by leadership factors. Indeed, the narrow interest of a given leadership have determined a whole destiny of nations and societies...As we move in the new century and Africa faces up to its challenges, it is important that the leadership factor is given due attention [2].

Dada also adds the voice of the former secretary-general of the United Nations, Mr. Kofi Annan [11]: "It is time for Africans to hold their political leader and not colonialism responsible for the civil wars and economic failures that ravage their lives" [2].

The former Nigerian President, Olusegun Obasanjo [12] is equally cited as one of the main political commentators who blame African political leadership for the failing of the continent on the global scene:

In 1960, whatever parameters you look at, whether social or economic indicators, Africa has declined compared to the rest of the world, particularly when measured against those parts of the world that were comparable to us at that time such as Asia... Why are we (SSA) failing while the rest of the world is succeeding, Africa is not less endowed as other parts of the world? I believe one-word answers that question-LEADERSHIP [2].

In the same vein, Dada cites K. Y. Amoako [13] as quoting the ECA Executive Secretary as underscoring "the importance of good political leadership at the highest level if the continent is to realize sustainable growth and poverty reduction on the continent." He goes on to quote the Ugandan President, Yoweri Museveni [14] as saying "Africa's slow industrial transformation from subsistence agriculture has been a result of bad leadership..." Next, he cites Festus Mogae [15], the Botswana President arguing that:

Peace and security, along with stable economic, political, and social environment are indispensable for creating conditions that will attract investment in Africa. Africa could not afford to fail to address the need for domestic, political and economic reforms in the context of good governance-good leadership [2].

Dada concludes this section by quoting Chukamba [16] who is contending that:

The lack of employment capacities and economic stagnation should be blamed squarely on her (African) leaders who put their interest first. It is such selfishness by leaders of most African countries that have seen the allocation of public resources to non-performing sectors that they use to siphon out public funds Dada [2].

Although Abiodun Alao [5] did not make any direct connection between the looting of Nigerian public treasury by Generals Ibrahim Babangida and Sani Abacha and their penchant for initiating and implementing peacekeeping missions, and considering the level of misappropriation of public funds and official corruption attributed to the two generals during their tenure as military heads of state, it is very doubtful if the peacekeeping missions was never used as a way of allocating resources to a sector where siphoning of public funds was carried out. Whether the peace support operation in Liberia and Sierra Leone was used to loot public funds or not, Abiodun Alao believes that the level of corruption at that time was unprecedented:

Again, while corruption is not altogether an uncommon practice in Nigeria, the scale at which this went in the 1990 decade was unprecedented. The three administrations that ruled during the period have been accused of graft of un-paralleled level. For example, the Babangida administration allegedly "democratized" looting. But while Babangida still gave allowance for culpable deniability, the Abacha administration removed all forms of cover from the looting of national treasury. Till date, the Obasanjo administration is still trying to recover some of the money the Abacha family has stocked away in foreign banks. Even the short period of General Abdulsalaam was not spared of grafting, as the government was alleged to have issued out spurious contracts during the brief period of its stay in power.... [5]. 
Meanwhile, between ten and twelve billion US dollars are being speculated by government official including former President Olusegun Obasanjo as the total amount of money spent from 1990 to 1999 on ECOMOG peace support operations in Liberia and partly Sierra Leone with no official records available for that period as earlier note.

Analyzing the origin of the African leadership crisis, Dada cites Bewaji [17] as stating that:

Contemporary Nigerian leadership is a carryover from British style of rulership during the colonial period. The colonial ruler group were 'foreigners' and did not mix with locals, they had no reason to, and they did not see their destinies as tied up with that of indigenous Nigerians. At independence, the inheritors of power were rulers who descended from an elite group who were distant from the people they governed, being that as a consequence of their acquisition of Western classroom based education they felt they were only nominally part of the masses of the people, they had lost touch with the people as a consequence or absence of their education, they failed to see themselves as part of the people who had invested in their acquisition of Western "education" and being distant, they failed to understand their heritages, values, culture and histories and as a consequence, their aspirations were not those of the people... [2].

In order to buttress the above argument, Dada quotes Symthe and Symthe [18] as stating that:

Already there is discernible among the new elite a sense of separation from the less privileged classes, which they betrayed unconsciously through referring "this people" or "the uneducated classes" which are the indicative of distinction between those who "belong" and those who are outside the fold as well as a growing sense of being "better" than some of their fellow Nigerians [2].

According to Dada, Symthe further stresses on this issue that:

This lack of identity with the masses follows the example of the British who evolved a selfcontained colonial way of life characterized by frequent home leaves and few, if any social or cultural contacts with the indigenous population. As Nigerians, who have acquired education and a higher standard of living they have found little common interest to share with the average person who lives in mud houses without amenities [2].

Furthermore, the Symthes observe, according to Dada, that:

A member of the elite (political class) is rarely reported in association with the masses except during political rally, when they make campaign speech, or on such an occasion as a crowd of on-lookers. Even on such occasions, the elite do not rub elbows with their less privileged fellow Nigerians; they are sheltered from the crowd by the police, an official escort or some rail or raised platform [2].

Dada finally cites Bewaji in this section as concluding that:

At independence in Nigeria, the political elites were a pack of visionless, simple-minded people who thought that the world would wait for them...Because of lack of understanding of the concept of leadership, coupled with poor preparation for leadership, what was more important is attainment and retention of power as a means of oppressing their hapless compatriots. Thus, power became an end in itself... [2].

Dada identifies two major factors motivating the poor political leadership in Africa. These according to him include internal and external forces. He lists followership factors including inactive criticism, followers who believe in feel-safe method of divining leadership, limited knowledge of followers, no deliberate efforts to select leaders, the collapse of youth up-bringing, character reference is not required and background check done, and the sidelining of the African cultural values and leadership as internal factors and lists colonial legacy, and the acceptance of bad leadership by Western countries as the external factors.

Dada explains that bribery and corruption were part of the colonial legacies. He goes on to illustrate this argument with the citation of Olojede [19] stating that:

The dirty secret of the Western world is that government and banking institutions, in Europe and America find it convenient to let Africa's ruling kleptocracy make off with the family silver, so long as it ends up in bank accounts in London, Washington and Switzerland. Just a couple of years ago, during an unrelated investigation of Riggs National Bank in Washington, Congressional Investigators found that Exxon Mobil secretly deposited more than USD 700 million in the personal accounts of President of Equatorial Guinea, Terdoro Obiang Nguema Mbasago. These deposits, which could not be adequately 
explained as anything other than corruption, never led to any Exxon Mobil executives being tried for contravening US law [2].

Dada concludes with this evidence that corruption in the African polity came from outside and warns that this is no excuse why Africans will not be held liable since according to him it takes two to tango. On why the western countries tolerate poor leadership for Africa and other developing countries, he cites Bewaji who contends that:

...who wants another Singapore or Hong Kong in the Caribbean or in Africa...If this region becomes self-sustaining, who will be lackeys to the metropolis from which ultimate intellectual and material power devolve? ... if true leaders emerge in this post-slavery, post-colonial societies, where would the sustenance of the metropolis, in the form of unending payment of bogus national debts be derived, and markets for all kinds of manufactured goods, as these leaders will instill discipline in the cultures, economies and peoples, making them independent ... Hence, the longer there are cerebrally challenged and culturally defective leaders in these post-colonial colonial societies, the better for the economic and political domination by the former colonial masters... [2].

Still on this poor leadership issue, Dada argues that:

Many African leaders have little incentive to practices of good governance as reforms generally work against their self-interests, which they place over the national interest. Such leaders usually can achieve their personal goals-personal financial enrichment, unbridled power, ethnic/regional superiority or domination etc by plundering their nation's resources. Good governance, by requiring transparency, accountability, control of corruption, protection of civil liberties, political and economic freedom etc obviously works directly against the self-interests of many political leaders and their cronies, and ultimately result in loss of power [2].

Writer after writer provide catalogs of problems facing the Nigerian armed forces operation in Liberia and Sierra. Some of these are either serving or retired military officers some of whom served in ECOMOG in the 1990s. The rising level of poverty in Nigeria is a clear evidence of the lack of effectiveness of the Nigerian political leadership in the country. The leadership of a country ravaged by poverty can only be mocked at if they try to play a leading role in international affairs because they cannot go out to the international arena to put out a fire when their own house is on fire but ironically this was what Nigeria did in Liberia and Sierra Leone in the 1990s.

This is why Nigeria has often been ridiculed instead of being praised for its peace-keeping efforts. Recent studies indicate that the poverty in Nigeria is increasing rather than decreasing despite all the billions of dollars that have been spent over the years to eradicate poverty as a way of enhancing economic development. For instance, according to Mike Obadan [20], in 1980, 28.1 percent of Nigerians live below the poverty line. In 1985, that moved up to 46.3 percent of Nigerians living below the poverty line. By 1996, the number of poor Nigerians has moved up to 65.6 percent and it keeps growing. So, in the year 2000, 70 percent of Nigerians have become poor and poverty continues to expand. Recently, the Punch Newspapers online reported that more than 94 million Nigerians live in poverty (https://punchng.com/94m-nigerians-currently-live-below-poverty-line-world-poverty-clock/) There is therefore, the need to review and analyze corrupt and failed political leadership responsible for creating poverty in order to create a counter measure to the pattern used by the shameless criminals to put an end to the despicable act [20].

According to Mike I. Obadan, "The description of Nigeria as a paradox by the World Bank 1996 has continued to be confirmed by events and official statistics in the country. The paradox is that the poverty level in Nigeria contradicts the country's immense wealth. Among other things, the country is enormously endowed with human, agricultural, petroleum, gas, and large untapped solid mineral resources. Particularly worrisome is that the country earned over US\$300 billion from one resource - petroleum - during the last three decades of the twentieth century. But rather than record remarkable progress in national socio -economic development, Nigeria retrogressed to become one of the 25 poorest countries at the threshold of twenty-first century whereas she was among the richest 50 in the early-1970s" [20].

As stated earlier, the key development parameter today is the level of poverty or prosperity of a nation which is measured using the United Nations Human Development Index (HDI). According to Mike I. Obadan [20], one of the greatest challenges facing Nigeria as a nation in terms of poverty eradication for economic development and the development of workable democratic institutions and good governance is the selfish attitude of the political elites. They are egocentric and use their political power and public office to achieve their selfish ends.

The former military leader Ibrahim Babangida for instances had been accused by many analysts that he was in Liberia and Sierra Leone for his personal interest in Samuel Doe and Joseph Momoh [5]. Nigerian leaders are not in Public service or politics to help develop their community and the country but rather to grab any material thing that they 
can lay their hands on for personal gains. This problem is as old as the modern independent African nations since they were granted political independence. It is an inherited problem from the colonial leadership [20].

Dada [2] and Obadan [20] share the view that the selfish attitude of the Nigerian political elites is one of the greatest challenges facing Nigeria as a nation in terms of poverty eradication for economic development and for developing a workable democratic institutions and good governance. The Nigerian political elites emerged once the process of decolonization began. The pioneers participated in or led the independent movements that eventually led to the independence of the country. Political independence was granted to Nigeria like most of the African former colonies from the late 1950s and to many more in the 1960s and to others much later. Not too long after independence all the high hopes of reaping the benefits of freedom and self-governance were dashed by selfish misappropriation of public funds and in-fighting for power by the new political leaders [21].

The in-fighting for power came to a breaking point when the mandate of the political leaders who were elected by elections organized by the colonial authorities expired and they were due for re-election. They manipulated the electoral process and tampered with the independent constitution that guaranteed fairness to all sections of the nation with the intention of keeping power for life. The top leaders soon declared themselves presidents for life all over the continent. They also confiscated and converted all national resources into personal properties and fiefdoms. The new military establishments in Nigeria soon organized coups and counter-coups d'état citing the political instability caused by the in-fighting by the new political elites as an excuse. The people soon realized that the only freedom that they had really won from the colonial powers was the freedom to elect their own dictators and predators. Since then the noose has continued to tighten around the necks of the poor and the common folks until now [20].

In reviewing the African colonial experience, two questions easily come to mind. The first question is, if European colonists were exploiting the resources and exporting them to their home countries in Europe without repatriating the proceeds back to Africa, was it not because they belonged there? Why should African political leaders do the same? The second question is, why is it that the Asian countries that suffered the same fate with African countries like Nigeria quickly turned around and do the opposite of what the colonial masters were doing? This is why the actions of the Nigerian political elites can never be defended. For this reason, a critical look has to be taken at the political elites and why they have to be held accountable for the political catastrophe that they have brought to the country since independence in 1960. It is often said that among every 7 African there is a Nigerian and so it is natural that it becomes the first candidate for the detail study of this ruling elite political fiasco [2].

The Nigerian political elites deliberately practice the selfish exploitation of the natural and human resources of the country for personal gains as it was practiced by the colonial administration. They were educated elites who emerged as political leaders during the struggle for independence from the United Kingdom of Great Britain before and after independence in October 1960 [2].

Nigeria is one of the nations that has been worst affected by the failures of the political elites and that is the issue being discussed. The Nigerian political elites are therefore seen as the greatest challenge facing the country in terms of developing workable democratic institutions and good governance which economic development is bound to bring about.

The first and foremost evidence of this political failure by the political class is their inability to conduct a free and fair election just as it was pointed out again by Abiodun Alao in his paper. The Nigerian politicians look at the whole electoral process as a do or die affair. They use all kind of tactics in their effort to win the election by all means. Those that have lots of money bribe the electoral officers to fix the results for them. If the electoral officers refused to be bribed, they would pay ordinary citizens to go out and rig the election by voting multiple times. If this attempt is stopped by the electoral officers, they would pay criminal element to snatch the ballot boxes at gun-point. If the electoral officers resist this threat of violence, the hired criminals will sometimes actually kill the electoral officers to achieve the objective of the politician who sent them. These issues are very relevant because there is no way poverty can be reduced or eradicated to enhance economic development in this very corrupt situation. The rule of law needs to prevail in order to put corruption into check, promote economic development and minimize poverty in the society [20].

Electoral officers who refused to accept bribe are sometimes kidnapped at gun-point and forced to write and publish false results. During the recently concluded gubernatorial elections in Nigeria in 2011, despite the fact that the present government is trying to fix these electoral problems, there was a reported incident in which an electoral officer was kidnapped and forced to falsify the result. According to an article entitled "I was kidnapped to alter gov resultsZamfara returning officer" written by Muhammad Sabiu and published in the Nigerian Tribune of April 28, 2011, an electoral officer named Mainasara Nasiru told the reporter that he was kidnapped at gun-point by two mobile police men attached to the deputy governor's office and forced to alter the result in favor of one of the political parties. He narrated 
to the reporter that he initially refused to alter the result but when they threatened to kill him he obeyed them and when he reported the incident to his boss, he called the overall boss of the electoral commission and gave him the original result over the phone. The original result was finally published.

Hired assassins are sometimes engaged by politicians to eliminate their opponents directly. This is one of the most gruesome aspects of the evils of the Nigerian politicians. Sometimes it is entirely two different communities that are at each other's throat at the instigation of their political leadership. People who are familiar with the origin of the Niger Delta crisis in Nigeria know too well that it all began with disbanded armed political thugs who later volunteered for the Niger Delta struggle for resource control with no violence against innocent civilians and no kidnapping for ransom but were later infiltrated by criminal elements. They began to go on rampage kidnapping people for ransom, committing armed robbery, getting paid as hired assassins and finally ended up in the creeks as crude oil bunkerers. It was an attempt to stop them from bunkering that resulted into the vandalization of pipelines and other oil installations.

It was the former political tugs who were hijacked by the political class and converted to be freedom fighters for the longtime marginalized Niger Delta people. The politicians do this to gain attention from the mostly Northern HausaFulani political class that have dominated the national political leadership since independence and have refused to listen to the complaints of the suffering people of the Niger Delta and their aspiring political class. The political tactics used by the Niger Delta politicians can be said to have paid off today because the pressure mounted on the federal government through the disruption of oil production on which the government depends for nearly $100 \%$ of its revenue forced them to accept a Niger Deltan as a vice-president. The vice-president, Dr. Goodluck E. Jonathan had since assumed the post of a substantive president following the death of his boss. In addition, he also won his own four-year mandate in an election that international observers acclaimed to be free and fair and the best that the country has ever conducted since independence.

The political elites' pioneers were all educated by the colonial authority. Most of them also worked for the colonial administration where they learned the art of governing the new country handed down to them for evil or for good. Key among the pioneers were Dr. Nnamdi Azikiwe, an Ibo Eastern Christian who led a more national NCNC Party and Chief Obafemi Awolowo, a Yoruba Western Christian who led a more tribal based Action Group Party based in the Yoruba area of the West and the other key pioneer was Abubakar Tafawa Balewa, a Hausa-Fulani Muslim who represented the Hausa-Fulani Muslims interests of the North of the country. With each large tribe represented by a political leader, the country was set for inter-tribal political conflict as a result of personal and sectional interests.

The pioneer political elites began to acquire wealth and personal influence but they were less aggressive than the next generation of political elites that follow them. They started with some goodwill of trying to be part of the history of the new country that was just emerging from the colonial yoke. They wanted to prove to be good state men and patriots. However, the exalted political offices came with some material benefits which set them apart from their peers who were not in politics. This was the main reason why the next generation of political elites became more aggressive in wealth acquisition. The other reason was that with the passage of time, hero worship of local celebrities who displayed enormous amount of wealth and donate generously on fund-raising occasions has become very popular. Traditional rulers made the situation worse by granting chieftaincy titles to local celebrities who donated large sums of money towards their community projects and Nigerians love flamboyant titles a lot especially politicians. It may interest you to learn that nearly all major political leaders have one phoney chieftaincy title, honorary doctorate title or a religious title like "JP" (Jerusalem Pilgrim for Christians) or "Alhaji” (Muslim pilgrims).

Things got worse when earnings in other occupations were no longer enough to sustain a decent living for the educated elite. It has now come to a point that the driving forces behind the participation in politics are survival, greed and the desire to acquire wealth. This is not to rule out the possibility of having a few politicians who are there to make a name in history. (Let this be made clear to avoid any misunderstanding). For example, the late President Umaru Ya'radua and his successor Dr. Goodluck E. Jonathan are often cited as a new breed of the Nigerian political elites who were not corrupt and who were there to turn things around for the better. In fact, aside from the international observers who rated very high the recently conducted presidential elections in Nigeria in April 2011, the United States government has also praised the polls calling them the best ever conducted in the country since independence. The question now is, are other politicians going to follow his good example? Probably not! The European Union has just issued a statement on the recently conducted gubernatorial elections in Nigeria over which the governors have more control saying that so many fraudulent practices like under age voting and ballot box snatching were rampant. This is an eloquent reminder of the proverbial statement that 'a tree cannot make a forest'.

There have been series of cases where the Nigerian political elites just awarded themselves very lucrative contracts worth millions of dollars and simply disappeared with the contract money without doing any job. This is one of the main sources of public corruption in the Nigerian polity and the main reason why no real development takes place, 
talk less of reducing or eradicating poverty. "EFCC Nabs 3 Reps Over N6bn Power Funds" is the caption of an article in the Nigerian Tide Newspapers of May 13, 2009 written by Ike Wigodo in Port Harcourt. Wigodo writes that three members of the Nigerian House of Representatives were arrested by a Nigerian anti-crime tribunal, the Economic and Financial Crime Commission for embezzling about $\$ 40$ million meant for rural electrification, a key infrastructure aimed at reducing poverty.

He adds that the Rural Electrification Agency awarded the contract and all the payments were made on December 30, 2008 but the jobs were not done. He also writes about another contract worth about \$5.66 million for the provision of school furniture. The contract was awarded and the entire sum paid but no job was done. Finally, Wigodo also reports another case in which a former state governor, Chief Orji Kalu is on trial for misappropriating about \$20 million of state funds while he was the executive governor of Abia State of Nigeria. He notes that Chief Kalu was also linked to some real estate properties in the United States, The United Kingdom and Nigeria. The instances of these mismanagements are virtually endless.

Recently, a state governor admitted while talking to journalists that he was unpopular with the political elites in his state for his refusal to award contracts to politicians. In an article entitled "Why I'm unpopular among political elites in Edo-Oshiomhole" written by Simon Ebegbulem and published on page 34 of the Nigerian Vanguard Newspapers of March 20, 2011, Governor Adams Oshiomhole explained that he preferred to award contracts to competent contractors and this angers his fellow politicians. He added that he resisted the temptation of awarding "the contracts to politicians who may eventually abandon the jobs and "share the money" [22]. The governor concluded that he was able to complete the projects that he planned to carry out but he was paying the political price of being unpopular to disappointed politicians. This revelation is a clear manifestation of the Nigerian political class unwillingness to collaborate with any of their counterparts who tries to turn things around.

Nigeria is the largest producer of crude oil in Africa and the number 6th country in the world for the same commodity, yet it continues to be listed as one of the poorest countries of the world. Aside from the inability of the Nigerian political class to conduct a credible election, the other evidence of their failure as a ruling class is lack of physical development and non-provision of essential services to the population. Most infrastructures of the government are in various stages of decay and deterioration. Roads, bridges, railways, schools and colleges and other public structures all show the signs of wear and lack of maintenance. The supply of electricity is at best epileptic and less than $60 \%$ of the population has access to it once in a blue moon. The entire country is run on the basis of own-operated generators. The public waterworks are barely sufficient for the government institutions let alone the supply of the residential areas of the cities. The whole cities are flooded by water hawkers who usually obtain their untreated wares from local borehole operators. This has become one of the most lucrative businesses for local entrepreneurs. This lack of basic infrastructures and public utilities are some of the reason why poverty continues to expand in the Nigerian population.

Refuse collection which is taken for granted in most countries of the world is another clear evidence of the failure of the political class in Nigeria. Just as every individual provides himself or his institution with electricity and water, which is how they also take care of their refuse. It is not unusual to see women and young boys carrying refuse baskets on their heads in cities, towns and villages collecting other people's refuse for a fee. After independence the public works department used to be responsible for the collection of refuse and streets maintenance. The Nigerian political leadership is simply sharing the money meant for that job. It is done in different ways. For example, they sometimes simply embezzle the funds through what is popularly known ghost workers or non-existing workers. However, if the boss of the perpetrator makes this scheme impossible, he may decide to actually recruit people but instead of making them to work and earn their salaries in full, they will just come and sign for the salaries to be shared between the two parties. This is a very common practice among local political appointees and it is mostly done with relatives and family members.

Nigerian political elites encourage their ethnic communities and constituencies to spend all of their time and resources antagonizing others instead of working for the greater good of the country and communities. It is not uncommon to hear of two rival communities fighting and destroying each other's homes and means of livelihood like farmlands, herds of goats or cattle or fish-farms. Inter-communal violence has become one of the greatest challenges facing Nigeria as a nation. It interrupts both community and national development programs. All development and economic activities are usually forced to stop as a result of the inter-communal crises. Sometimes thousands of people are internally displaced because of this inter-communal violence with no basic necessities of life and thereby plunging the people deeper into more poverty.

The various communities that make up the country have been fighting each other in inter-tribal or inter-religious warfare. Almost all of the crises usually have political motives. The political elites usually ignite these crises and benefit 
from the outcome of the settlements that follow. Without going into the distant past, it will be recalled that the recently conducted presidential election ended up in very violent riots that claimed the lives of more than five hundred persons even though the international observers proclaimed it to free and fair. The truth of the matter is that the suspicion between the different tribal and religious groups is so deep that no one would like to trust the other party to rule over him or her. If a Northern candidate had won the election, the South would have protested too but in a peaceful way. The recent election was an exception though.

In the past, there used to be no elections at all. The political leadership in-charge of any locality will simply ask his party faithful to come to his office and thumbprint all the ballot papers. Before the advent of the proliferation of camera mobile phones, they used to allow people to come out and cast their ballot and then simply asked the electoral returning officer to write any result of their choice on the final result sheet. This practice has not been possible so far during this electoral process because the voters were encouraged to wait until the final results are posted at every polling booth before leaving and that is why it has so far been very transparent this time except for some few instances during the last part of the elections. With this new development one would have been happy that the whole episode of electoral fraud is over but the desperate political elites who could not have their way with the transparent electoral process are looking for other ways of discrediting the whole process so that they can have their way. They unnecessarily cried foul and call out their supporters to riot, beat, torture and even murder their opponents and supporters of their opponents and then moved on to plan further destabilizing tactics. Here again the recent post-presidential elections violence is a good example. Despite the world-wide acclamation that the presidential elections were free and fair, the opponent of President Goodluck Jonathan, General Mohammadu Buhari incited his followers to come out and riot just because he lost the presidential elections of April 2011 causing the death of more than five hundred Nigerians.

The misrule by the Nigerian political elites is closely tied to the electoral fraud because they need to steal their mandate from the electorate to be able to steal their resources and get away with it. They are aware of the fact that if they have to be voted into office, then they have to account for their stewardship to the people who elected them or they would surely lose their power. For this reason, until the new administration of Dr. Goodluck Jonathan came into office, no top political leader used to be concerned about conducting a free and fair election. The people are simply abandoned to their fate and the government is unable to provide the basic services that make a government what it is, 'a government'. It was mentioned elsewhere in this paper that individuals provide themselves with electricity, water and dispose of their own refuse. These are some of the basic functions of government but the Nigerian government is unable to perform them consistently. There is absolutely no welfare program for the elderly, the disabled, children, widows and the jobless and members of these groups constitute a large proportion of Nigerians living in poverty. Besides, the unemployment rate is about $80 \%$ in the rural areas. Daily life is still based on the Stone Age doctrine of survival of the fittest. In this circumstance, will any politician think that anyone in his right frames of mind will come out and freely vote for him? This is why the politicians have decided to be stealing the people's mandate. The failure of Nigeria to perform the most basic functions of government in a consistent manner is one of the reasons why it is sometimes referred to as a failed state (See the next paragraph).

The inability of the Nigerian ruling class to run the country successfully is another reason why political analysts and even Nigerian politicians in the opposition sometimes classify the country among failed states. In an article entitled "Nigeria is a failed state, says ex-minister" published by the Nigerian Punch Newspapers on May 8, 2009, the author of the article, Emmanuel Obe explains that the former minister classified Nigeria as a failed state because it "...had failed to live up to the expectations of a modern state, having been crippled by corruption, politics of patronage and collapse of basic infrastructure". He adds that the Economic and Financial Crime Commission ought to arrest and question the former president Olusegun Obasanjo for saying that he was not elected to build roads and provide electric power after misappropriating millions of dollars meant for the building of infrastructure while in office. He concludes that the fact that Nigeria is unable to refine its own crude oil further demonstrates that it is a classical non-functioning state. All these failings on the part of the government explain why the numbers of Nigerians that live on one dollar or less a day continue to grow.

The top political leadership is very corrupt, inefficient and loyal to one's own ethnic community only. The main reason why democracy and good governance in Nigeria is still an illusion is that the majority of them are very corrupt or inefficient or both. For instance, the Nigerian Guardian Newspapers of August 17, 2009 reports that over \$101.33 million was missing in the NNPC Excess Crude Account following an audit. The Nigerian National Petroleum Corporation (NNPC) is the government agency responsible for the oil industries in the country and it is under the direct authority of the presidency. In an article captioned "Audit exposes excess crude account fraud, indicts NNPC", Mohammed Abubakar who was writing for the Nigerian Guardian Newspapers from Abuja reports that several illegal withdrawals were made from the excess crude account without regard for the due process of making such withdrawals. He adds a catalog of the illegal withdrawals according to a report by the office of the Auditor-General of the Federation of Nigeria which cannot all be listed here. The implication of this is that no real governance takes place when leaders at this level cannot be 
trusted to perform their duties honestly. They basically use their office to enrich themselves, their immediate families, friends and community. The Nigerian political elites have no feeling of patriotism for the nation that was handed down to them at independence.

Again, in the case of Nigeria, the politicians are so unpatriotic that they only discuss how to share the national cake or the proceeds from oil sales. They also often refer to Nigeria as mere geographic expression created by the British colonial authorities. Several past heads of state have been accused of looting the nation's treasury with their families and friends. Two cases come readily to mind when one thinks of looting of the nation's treasury. The case of the late military dictator, General Sani Abacha is very well documented. In a follow-up report by the Nigerian Guardian Newspapers of May 21, 2009, it was reported that 450 million dollars was still missing out of 3 billion dollars he stole while in office from 1993 to 1998 . The article is entitled “\$450m Abacha's loot can’t be traced, says UN agency” was jointly written by Lemmy Ughegbe and Terhemba Daka in Abuja. The article goes on to list the various sums of money stolen by the late dictator which have been recovered totaling $\$ 1.9$ billion. The other one is that of Chief James Ibori, the former governor of Delta State who was then standing trial for money laundering in a London court. His own case was reported by the Niger Delta Standard Newspapers of April 29, 2011 by Admin in London in an article entitled "Ibori's Trial starts in London." He is accused of stealing several million dollars while serving as a governor in Delta State and charged with laundering the money in London banks.

You may want to recall that an international NGO known as Transparency International had cited Nigeria many times in the past as the most corrupt nation on earth especially during the years of military dictatorship.

As long as the Nigerian political elites refuse to change for the better, there can never be good governance or the real benefit of democracy can never be obtained by the ordinary Nigerian and no internal security can be guaranteed. The most embarrassing evidence of the failure of the Nigerian political class is their failure to provide regular electricity to the nation despite the abundant supply of natural gas which can power as many gas turbines as they wish to build to light up the country. During the past government of General Obasanjo more than 16 billion dollars contract was awarded for the electrification of the country but it was simply shared by the politicians. When a newspapers' reporter asked him about the money, he simply referred him to the energy minister. Meanwhile, Nigerians continue to struggle for survival in darkness. Most foreign manufacturers who would have liked to take advantage of the low labor costs in the country to invest in manufacturing are simply scared away because of the enormous additional costs of powering their productions with generators. This is a country that has more than $80 \%$ of unemployment and yet nothing is being done to attract big private investors into the economy. How can poverty not continue to expand in these situations, and how can internal security of the nation be guaranteed?

Finally, there is no doubt that the Nigerian political leadership has failed in every respect to lead the country in a responsible manner. This fact was clearly acknowledged by some prominent Nigerians from various social and political spectrums during the ceremonies marking the $10^{\text {th }}$ Anniversary of the re-introduction of democratic rule in the country in 1999. In an article published by the Nigerian Guardian Newspapers on May 30, 2009 captioned "Democracy at 10: Ya'Adua's Agenda Hasn't Worked”, Nigerian former senate president, the Arch Bishop of Lagos, a former presidential liaison officer, several university professors and former governors agreed that the ten years of democratic rule have not been successful or effective but rather dominated by corrupt leadership.

The majority of them also agreed that if the military stays out of the political affairs of the nation, things might eventually improve with the civilians correcting themselves. One of the efforts usually mentioned as an evidence of selfcorrection in progress is the establishment of the Economic and Financial Crimes Commission (EFCC) which investigates and jails corrupt politicians. However, its performance too has not been perfect as some critics accuse it of treating some corrupt politicians as sacred cows or persons above the law.

\section{CONCLUSION}

In Conclusion, considering the failure of the political leadership in Africa or Nigeria, the logic is very simple. One cannot ask the people for political mandate without giving anything in return once the mandate has been granted. This explains why Nigerian or African political elites always resort to electoral fraud to obtain and conserve political power. The political elites have no intention of serving the people. They join the political party to obtain favor in the form of contracts. Once a contract has been secured, they will execute just about one percent of the contract or do no job at all and collect the entire payment for the undone job. Nigeria's internal security and economic standing in the world for poverty and developmental ranking will not change unless the country's political leadership change their present attitude. With the number of Nigerians living below the poverty line at 71.5 percent [20], it shows that much more needs to be done to reverse the trend. 
Note: The political elite here represent the military ruling class during the Liberian crisis.

Research Interests Include: Public Management, Public Policy/Administration, International Relations/Security, Peace Support Operations/Humanitarian Missions, French/Linguistics.

\section{REFERENCES}

1. Ake, C. (1996). Democracy and Development in Africa. Washington, DC: Brookings Institution.

2. Dada, O. J. (2007). Strengthening Africa Political Leadership Capacity for Development: Key Challenges. Paper delivered at the African Association for Public Administration and Management, Mbabane, Swaziland, September, 3-7.

3. Barikor, F. F. (2014). Assessing Nigeria's Regional Security and Contributions to ECOMOG Peace Support Operations in Liberia from 1990 to 1999. In Print in USA, Lexington Books, African Governance and Development Series, Edited by Olayiwola Abegunrin, Lanham Maryland, U.S.A.

4. Akintola, A. L. (2007). The Nigerian Navy Participation in Peace Support Operations since 1960. In Alexander Odareduo Ogomudia (ed.), Peace Support Operations, Command and Professionalism: Challenges for the Nigerian Armed Forces in the 21st Century and Beyond. Ibadan: Gold Press Limited.

5. Alao, A. (2006). Peacekeepers Abroad, Trouble Makers at Home: The Nigerian Military, National Politics and SubRegional Policy in the 1990s. In Olayiwola Abegunrin and Olusoji Akomolafe (eds.) Nigeria in Global Politics: Twentieth Century and Beyond Essays in Honor of Professor Olajide Aluko. New York: Nova Science Publishers, Inc.

6. Nweke, C. O., Alisi, C. S., Okolo, J. C., \& Nwanyanwu, C. E. (2007). Toxicity of zinc to heterotrophic bacteria from a tropical river sediment. Applied Ecology and Environmental Research, 5(1), 123-132.

7. Adei, S. (2003). Overview of university level education in Africa. Chapter, 4, 90-108.

8. Barikor, F. F. (2017). Current Trends in Public Management in Nigeria-An Attempt to Answer the Question, IS NIGERIA A FAILED STATE? And A Practical Manual for Public Management in Nigeria, Published by FIBAG International Services, Port Harcourt, April, 2017.

9. Okanlawon, A. R. (2007). The Nigerian Air Force in Peace Support Operations. In Alexander Odareduo Ogomudia (ed.), Peace Support Operations, Command and Professionalism: Challenges for the Nigerian Armed Forces in the 21 st Century and Beyond. Ibadan: Gold Press Limited.

10. Salem, A., Ravat, D., Gamey, T. J., \& Ushijima, K. (2002). Analytic signal approach and its applicability in environmental magnetic investigations. Journal of Applied Geophysics, 49(4), 231-244.

11. Annan, K. (1998). Statement by United Nations Secretary General, Mr. Kofi Annan to the Opening of the Twentieth Special Session of the General Assembly.

12. Obasanjo, O. (2000). Address on the occasion of the formal Signing into law of corrupt practices and other related offences act. Abuja, Nigeria.

13. Amoako, K. Y. (2001). Fulfilling Africa's promise'. Millennium Lecture at, 10, 4.

14. Museveni, Y. (2003). Why Uganda, Nigeria Or the African Union? (No. 3). Centre for Peace Reseach and Conflict Resolution, National War College.

15. Mogae, F. G. (2003). Statement by His Excellency Mr Festus G. Mogae, President of the Republic of Botswana on the inauguration of Professor Bojosi Otlhogile Vice Chancellor of the University of Botswana, Saturday, 12.

16. Sastri, S. (2003). Madhavanidanam.

17. Bewaji, J. A. I. (2003). Beauty and Culture: Perspectives in Black Aesthetics: an Introduction to African Diaspora Philosophy of Art. Spectrum Books.

18. Smythe, H. H., \& Smythe, M. M. (1960). The new Nigerian elite. Stanford University Press.

19. Olojede, D. (2006). This is how the rot begins. Sunday Times, 41.

20. Obadan, M. I. (2012). Poverty Reduction in Nigeria: The Way Forward. Bn Economic \& Financial Review, 39(4), 2012.

21. Abegunrin, O. (2003). Nigerian Foreign Policy under Military Rule, 19661999. Westport, CT: Praeger Publishers.

22. Ebegbulem, S. (2011). Why I'm unpopular among political elites in Edo -Oshiomhole. The Nigerian Vanguard Newspapers of March 20, 2011, Lagos, Nigeria. 